\title{
果実発育期間中の気温がモモ“あかつき’ 果実の発育に及ぼす影響
}

\author{
羽山裕子 ${ }^{1 *}$ ・藤丸 治 $^{2} \cdot$ 岩谷章生 ${ }^{2} \cdot$ 伊東明子 $^{1} \cdot$ 阪本大輔 ${ }^{1} \cdot$ 岡田眞治 ${ }^{2} \cdot$ 樫村芳記 $^{1}$ \\ 1 農業・食品産業技術総合研究機構果樹研究所 $305-8605$ つくぼ市藤本 \\ 2 熊本県農業研究センター果樹研究所 869-0524 熊本県宇城市松橋町
}

\section{Influences of Temperature during Fruit Growing Season on Fruit Development of 'Akatsuki' Peach}

\author{
Hiroko Hayama $^{1 *}$, Osamu Fujimaru ${ }^{2}$, Akio Iwatani ${ }^{2}$, Akiko Ito ${ }^{1}$, \\ Daisuke Sakamoto ${ }^{1}$, Shinji Okada ${ }^{2}$ and Yoshiki Kashimura ${ }^{1}$ \\ ${ }^{I}$ National Institute of Fruit Tree Science, NARO, Tsukuba, Ibaraki 305-8605 \\ ${ }^{2}$ Fruit Tree Research Station, Kumamoto Prefectural Agricultural Research Center, Uki, Kumamoto 869-0524
}

\begin{abstract}
We compared changes in certain characters associated with fruit maturing such as fruit size, flesh firmness, sugar concentration and storability in 'Akatsuki' peach growing in Kumamoto and Ibaraki, under different weather conditions, to investigate the influences of temperature on the development of peaches. The average temperature of Kumamoto during the fruit growing period (from full bloom to harvest) was about $2^{\circ} \mathrm{C}$ higher than that of Ibaraki. The mean temperature during fruit maturing period (four weeks before harvest) was the highest in Kumamoto in $2004\left(25.7^{\circ} \mathrm{C}\right)$, and the lowest in Ibaraki in $2003\left(20.9^{\circ} \mathrm{C}\right)$. The time of the initiation of stone hardening, based on the degree of the endocarp lignification, was related to the temperature during young fruit (six weeks after full bloom), that is, the higher temperature tended to shorten the period until the initiation of stone hardening. However, the interval from stone hardening to harvesting time was similar in all years and places investigated, although the weather conditions differed. Furthermore, based on the harvesting time, changes in various characteristics of fruit maturity were similar regardless of the place or year. Moreover, the storability was not significantly different when fruit were harvested at firmness of around $30 \mathrm{~N}$. These findings suggested that fruit maturing or ripening of 'Akatsuki' peach was unaffected by the temperature during the fruit growing season.
\end{abstract}

Key Words : fruit maturation, shelf life, stone hardening

キーワード：日持ち性，果実成熟，硬核

\section{緒言}

「気候変動に関する政府間パネル」（IPCC）が 2001 年に 発表した「第 3 次評価報告書」（Houghton ら，2001）では, 地球の平均気温が 1990 年から 2100 年までの間に 1.4 $5.8^{\circ} \mathrm{C}$ 上昇すると予測している。休眠，発芽，開花，果実 の成熟等果樹の生育は気温に大きく左右される（杉浦・ 本條，1996, 1997）ことから, 地球温暖化による気温の上昇は 果樹栽培に大きな影響を及ぼすものと危惧される。（独）農 業・食品産業技術総合研究機構果樹研究所が平成 15 年度に 47 都道府県の果樹関連試験研究機関を対象に実施したア ンケート調査によると, 果樹農業に対する温暖化の影響に ついては,「温暖化の影響はみられない」とする回答はなく

2006 年 3 月 9 日 受付. 2006 年 9 月 11 日 受理. 本研究は（独）農業・食品産業技術総合研究機構運営費交付金 プロジェクト研究N o. 166「作物及び家畜生産に打ける気候温暖 化の影響解明とその制御技術の開発」の助成により行われた.

* Corresponding author. E-mail: hhiroko@affrc.go.jp
（黒田，2004; 杉浦ら，2004），生産現場においては地球温 暖化の影響が顕在化しつつあるものと考えられる.ただし， 多くの機関は「温暖化の影響らしき現象が起きている」と 回答しており，温暖化に起因寸るとの確証が得られている 現象は一部に限られるものと考兄られる。気温の上昇等気 象条件の変化が果樹の生育に及ぼす影響については不明な 点が多いため, 近年果樹の生産現場でみられる花芽形成の 不良, 生理的落果の増加, 生理障害の増加, 果肉の軟化等 の現象（黒田，2004）に温暖化が関係していると断定する ことはできない.

果実の発育は温度に影響されるが，その反応は樹種によ り異なり大きく二つのグループに分けられる（杉浦ら， 2004). 気温の上昇により開花時期が前進するとそれにとも ない収穫時期も前進する「前進型」と気温の上昇により開 花時期は前進するが収穫時期はほとんど変わらない，また は遅延する「拡大型」である。前者には, ナシ, モモ, ウ メ, 後者にはリンゴ, ブドウ, カキ等がそれぞれ含まれる. 拡大型では，気温の上昇によって果実発育期間が延長され 
るが，これは着色が遅延することが主な要因である（杉浦 ら，2004）。一方，前進型の果樹に打いては，幼果期の気温 の上昇が果実の発育速度を高め, 果実発育期間を短縮する ことが明らかにされている(栗原ら, 1965; Lombard ら, 1971; 志村ら，2001；杉浦ら，1995）が，果実成熟にともなら形 質変化に及ぼす影響は不明である.

果樹は樹体が大きく生育環境の制御が困難なことから, 果樹の生育に対する温度の影響を明らかにするためには, ポット植えした樹を用いることが多い.しかしながら,ポッ ト植えした樹の生育は圃場に栽植された樹とは異なると考 えられる，そこで，本研究では気象条件が異なる熊本と茨 城に栽植されたモモ ‘あかつき’を用い, 開花から成熟に 至るまでの果実発育過程に打ける様々な変化について 3 か 年調査を行い, 果実の発育と気温との関係を解析した。 た，同一の熟度で収穫した果実に打ける日持ち性を比較す るため, 熊本と茨城で生育したモモ樹からほぼ一定の果肉 硬度の果実を収穫し, 日持ち性の違いを比較・検討した。

\section{材料および方法}

\section{1. 材料}

試験には（独）農業・食品産業技術総合研究機構果樹研 究所（茨城県つくば市）扣よび熊本県農業研究センタ一果 樹研究所 (熊本県宇城市) の圃場に栽植されているモモ“あ かつき’ 樹（茨城：4 樹, 熊本：6 樹）を用いた。樹形は, 開心自然形（茨城）および平棚仕立て（熊本）であり，樹 勢は両地域ともに中程度であった。 また, 土壤条件は, 茨 城では淡色黒ボク土, 熊本では細粒赤色土であった。試験 は2003 年から 2005 年の 3 か年行い, 試験開始時の樹齢は, 茨城が 5 年生, 熊本は 4 年生であった。気象データはアメ ダス（茨城：つくば，熊本：甲佐）の測定值を使用した. 摘雷・摘果は慣行どおりとした. 満開後 55 日頃に半透明撥 水性の果実袋（ネクタリン 1 号, 小林製袋）を掛け，収穫 まで除袋しなかった。収穫は, 果肉硬度 $20 \sim 25 \mathrm{~N}$ を目安 に $1 \sim 2$ 日間隔で行った. 樹全体の花の約 $80 \%$ が開花した 日を満開日とし, 積算収穫果実数が収穫開始時における総 着果数の 50\%を超えた日を収穫盛日とした。 また, 満開日 から収穫盛日までを果実発育期間とした。

\section{2. 核の硬化時期の判定}

満開 40 日後から $3 \sim 5$ 日ごとに果実 10 果をランダムに 採取し, 果実の縦断面をフロログルシン塩酸液（フロログ ルシン $1 \mathrm{~g}$ をタノール $50 \mathrm{~mL}$ に溶解し, 濃塩酸 $25 \mathrm{~mL}$ 加えた液）で染色し，内果皮のリグニン化の度合いを福島 県果樹試験場の基準（阿部ら，2001）にしたがい5段階で 判定した。な拈，本論文に拈いては，志村ら（2001）の基 準にしたがい，硬核指数が 1 となる日を硬核開始日，硬核 指数が 4 となる日を硬核終了日とし，硬核開始日から終了 日までの期間を硬核期とした。

\section{3. 成熟にともなう品質変化の調査}

果実品質は着果部位により異なることが考えられるた
め，調査には樹冠の中央部に着生した果実を用い，あらか じめそれらの果実にラベルを付けた. 満開 70 日後頃から 5 〜10日ごとにラベルをした果実の中から 5 果をランダムに 採取し, 果径 (縦径, 横径, 側径) と新鮮重を測定後, 縫 合線をはさんだ両側中央部の果皮を薄く剥き，硬度計 (FT011，プローブ：直径 $8 \mathrm{~mm}$ 円柱形，富士平工業）を用 いて果肉硬度を測定した．果皮の地色は，モモ（白肉桃用） のカラーチャート（山崎・鈴木, 1980）を用いて評価した. さらに, 果肉硬度測定部付近の果肉から搾汁した果汁を超 純水で 25 倍に希釈し, 内部標準としてマンニトールを添加 した後, 陰イオン交換カラム（Bond Elut SAX, Varian）によ り精製し，スクロース，グルコース，フルクトース拉よび ソルビトールの含量を糖分析用カラム（SUGAR SC1011, 昭和電工）を装着した高速液体クロマトグラフィー（ポン プ: L-6200, 日立, 検出器 : RID-10A, 島津製作所) によ り測定した。な抏，各糖の含量の総和を総糖含量とし，あ わせて総糖含量に占める各組成糖の割合の変化も求めた.

\section{4. 日持ち性の調査}

果肉硬度約 $30 \mathrm{~N}$ を目安に収穫した果実を， $25^{\circ} \mathrm{C} て ゙ 5$ 日 間貯蔵した. 貯蔵 1 日後, 2 日後，3 日後，5 日後にそれぞ れ8 果を採取し, それらの果肉硬度を前項に記載した方法 で測定した。

\section{結 果}

\section{1. 果実発育期間における気温の推移および気温が果実の 発育期間に及ぼす影響}

満開日は, すべての調査年において茨城よりも熊本で早く, 特に 2003 年は両地域間に 10 日間の差があった（第 1 表）. な捛, いずれの地域に扣いても満開日は年次変動が大き く，最も早かった 2004 年と最も遅かった 2005 年を比較す ると, 熊本では 10 日間, 茨城では 8 日間の差があった。一 方, 収穫盛日は, 両地域で大きく異なり, 熊本では茨城よ りも $13 \sim 17$ 日早かった (第 1 表). このため, 果実発育期 間は, 熊本の方が茨城よりも短く, 熊本では 100 日間程度 であったが，茨城では 110 日間程度であった。

果実発育期間中の平均気温は, 熊本が茨城よりも約 $2^{\circ} \mathrm{C}$ 高かった (第 2 表). 同様に, 熊本は荻城よりも平均日最高 気温が約 $3^{\circ} \mathrm{C}$, 平均日最低気温が約 $1^{\circ} \mathrm{C}$ 高かった. 日照時 間の地域間差に一定の傾向はみられなかったが，降水量は いずれの年も熊本が多く茨城の約 2 倍以上であった.

満開から核にリグニンが蓄積を開始する平均的な時期 (満開 6 週間後）までの期間を幼果期とし, 幼果期の気象条 件を比較した (第 2 表). 平均気温, 平均日最高気温, 平均 日最低気温は，すべての調査年において熊本の方が茨城よ りも高かった. 特に 2005 年の気温は, 熊本ではすべての調 査年の中で最も高く, 一方茨城では最も低く推移したため, 平均気温の差は $3.4^{\circ} \mathrm{C}$ であった.

一時停滞していた果実肥大が再び始まる時期（収穫盛日 4 週間前）から収穫盛日までの期間を成熟期とすると, 成 
第 1 表 熊本と茨城に栽植されたモモ“あかつき’の満開日，収穫盛日拈よび果実発育期間

\begin{tabular}{|c|c|c|c|c|c|c|}
\hline \multirow{2}{*}{ 調査年 } & \multicolumn{3}{|c|}{ 熊本 ${ }^{\mathrm{z}}$} & \multicolumn{3}{|c|}{ 茨城 ${ }^{y}$} \\
\hline & 満開日 ${ }^{x}$ & 収穫盛日 w & 果実発育期間v & 満開日 $\mathrm{x}$ & 収穫盛日 w & 果実発育期間v \\
\hline 2003 & 3 月 29 日 & 7 月 8 日 & 101 日 & 4 月 8 日 & 7月 23 日 & 106 日 \\
\hline 2004 & 3 月 28 日 & 7 月 9 日 & 103 日 & 4 月 2 日 & 7 月 22 日 & 111 日 \\
\hline 2005 & 4 月 7 日 & 7 月 14 日 & 98 日 & 4 月 10 日 & 7月 31 日 & 112 日 \\
\hline
\end{tabular}

z熊本県農業研究センター果樹研究所 (熊本県宇城市)

$\mathrm{y}$ (独) 農業・食品産業技術総合研究機構果樹研究所（茨城県つくば市）

$\mathrm{x}$ 樹全体の $80 \%$ が開花した日

" 収穫果実数が着果数の $50 \%$ 超えた日

v満開日から収穫盛日までの日数

第 2 表 熊本と茨城に打けるモモ ‘あかつき’の果実発育期間中の気象条件

\begin{tabular}{|c|c|c|c|c|c|c|c|}
\hline \multirow{2}{*}{ 測定時期 } & & \multicolumn{3}{|c|}{ 熊本 ${ }^{\mathrm{z}}$} & \multicolumn{3}{|c|}{ 茨城 ${ }^{y}$} \\
\hline & & 2003 年 & 2004 年 & 2005 年 & 2003 年 & 2004 年 & 2005 年 \\
\hline \multirow{5}{*}{$\begin{array}{l}\text { 果実発育期間 } \\
\text { （全期間） }\end{array}$} & 平均気温 ${ }^{\circ}\left({ }^{\circ} \mathrm{C}\right)$ & 20.0 & 20.3 & 21.0 & 18.2 & 19.2 & 18.8 \\
\hline & 平均日最高気温 $\left({ }^{\circ} \mathrm{C}\right)$ & 25.5 & 26.6 & 26.9 & 22.7 & 24.7 & 23.7 \\
\hline & 平均日最低気温 $\left({ }^{\circ} \mathrm{C}\right)$ & 15.2 & 14.8 & 15.8 & 14.1 & 14.0 & 14.3 \\
\hline & 日照時間 $\left(\mathrm{h} \cdot \mathrm{day}^{-1}\right)$ & 3.9 & 5.3 & 5.0 & 3.9 & 6.5 & 4.8 \\
\hline & 降水量 $\left(\mathrm{mm} \cdot \mathrm{day}^{-1}\right)$ & 8.3 & 6.7 & 8.0 & 3.2 & 3.1 & 3.4 \\
\hline \multirow{5}{*}{$\begin{array}{c}\text { 幼果期 } \\
\text { (満開後 } 6 \text { 週間) }\end{array}$} & 平均気温 ${ }^{\mathrm{x}}\left({ }^{\circ} \mathrm{C}\right)$ & 16.2 & 16.0 & 17.5 & 15.2 & 14.7 & 14.1 \\
\hline & 平均日最高気温 $\left({ }^{\circ} \mathrm{C}\right)$ & 22.7 & 23.3 & 24.2 & 20.4 & 20.8 & 19.2 \\
\hline & 平均日最低気温 $\left({ }^{\circ} \mathrm{C}\right)$ & 11.0 & 9.5 & 11.7 & 9.9 & 8.8 & 8.2 \\
\hline & 日照時間（h・day $\left.{ }^{-1}\right)$ & 5.1 & 5.9 & 6.3 & 4.8 & 6.4 & 6.2 \\
\hline & 降水量 $\left(\mathrm{mm} \cdot \mathrm{day}^{-1}\right)$ & 6.8 & 4.4 & 4.9 & 3.0 & 2.1 & 2.5 \\
\hline \multirow{5}{*}{$\begin{array}{c}\text { 成熟期 } \\
\text { （収穫盛日前 } 4 \text { 週間） }\end{array}$} & 平均気温 ${ }^{x}\left({ }^{\circ} \mathrm{C}\right)$ & 23.7 & 25.7 & 25.4 & 20.9 & 25.1 & 23.8 \\
\hline & 平均日最高気温 $\left({ }^{\circ} \mathrm{C}\right)$ & 27.5 & 31.4 & 29.6 & 24.9 & 30.7 & 28.2 \\
\hline & 平均日最低気温 $\left({ }^{\circ} \mathrm{C}\right)$ & 20.4 & 20.9 & 22.0 & 17.9 & 20.5 & 20.2 \\
\hline & 日照時間 $\left(\mathrm{h} \cdot \mathrm{day}^{-1}\right)$ & 1.5 & 3.1 & 2.2 & 2.8 & 7.4 & 3.9 \\
\hline & 降水量 $\left(\mathrm{mm} \cdot \mathrm{day}^{-1}\right)$ & 16.2 & 5.5 & 17.9 & 3.8 & 2.1 & 6.1 \\
\hline
\end{tabular}

z 熊本県上益城郡甲佐町

$\mathrm{y}$ 茨城県つくば市

$\mathrm{x}$ 日平均気温の平均值

熟期間中の両地域間の平均気温の差は, 2003 年が $2.8^{\circ} \mathrm{C}$, 2004 年は $0.6^{\circ} \mathrm{C}, 2005$ 年は $1.6^{\circ} \mathrm{C}$ であった（第 2 表）。収穫 盛日前 4 週間の平均気温が最も高かった 2004 年の熊本と最 も低かった 2003 年の茨城との気温差は $4.8^{\circ} \mathrm{C}$ であった. す べての調査年に拈いて日照時間は茨城の方が多く, 一方, 降水量は熊本の方が多かった。

\section{2. 気温が核の硬化時期に及ぼす影響}

満開後約 40 日以降, 核の硬化とともにリグニンが急速に 蓄積し，硬核指数は 0 から 4 へと急激に変化した（第 1 図 A). 硬核開始日および終了日はいずれの年も熊本の方が荻 城よりも早かった。 また, 硬核開始日と幼果期の気温との 間には関係が認められ, 幼果期の日平均気温が高い年およ び地域ほど満開日から硬核開始日までの日数が短かった (第 1 図 A, 第 2 表). 一方, 硬核期間（硬核指数が 1 から 4 まで変化するのに要した日数) は2004 年の茨城でやや長 かったものの，地域間，年次間で大きな違いはなかった. また，硬核時期および期間は，収穫盛日を基準にして比較 すると，地域抢よび年次間で大きな違いは認められず，臣 ぼ同様の傾向を示した（第 1 図B).

\section{3. 気温が成熟にともなう果実形質の変化に及ぼす影響}

満開後 70 日以降の果実の果径（側径），果皮の地色，果 肉硬度, 糖含量の変化を収穫盛日を基準にしてブロットし た（第 2 図）。果径は, 収穫盛日前 30 日頃から急激に増加 した. 果皮の地色は, 収穫盛日前 10 日頃から急激に变化し た。果肉硬度は，測定開始時から直線的に低下した。糖含 量は成熟にともなって上昇する傾向が認められたが， ほと んど変化しない年もある等他の形質に比べてばらつきが大 きかった，果径，果皮の地色拈よび果肉硬度については， 收穫盛日を基準とした場合，いずれの地域，調査年におい てもほぼ同様の傾向で推移した。

成熟にともなら糖組成の変化を第 3 図に示した。 モモの 果汁に含まれる糖の大部分はスクロースであり，糖含量全 体に占めるスクロースの割合は, 成熟にともない顕著に増 加したが，収穫盛日の約 1 週間前からは一定で推移した. 糖組成の変化に地域による違いは認められなかったが, 2004年は両地域ともにグルコース扣よびフルクトースの割 合が低く，スクロースの割合が高かった。 


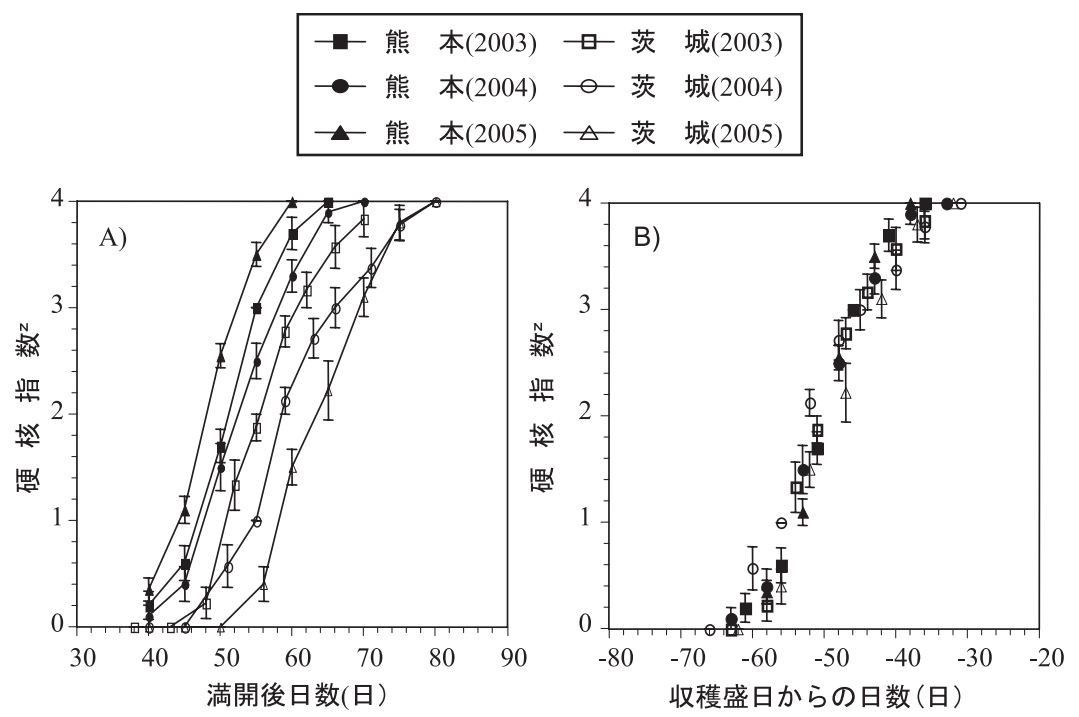

第 1 図 熊本と茨城に栽植されたモモ ‘あかつき’ 果実の硬核指数の変化

（A）満開日を基準としてブロット（B）収穫盛日を基準としてブロット (グラフ内のバーは標準䛊差を示す $\mathrm{n}=10$ )

z 福島県果樹試験場の基準（阿部ら，2001）に基づき評価

\begin{tabular}{|cccccc|}
\hline 口 & 熊 & 本(2003) & 口 & 茨 & 城(2003) \\
- & 熊 & 本(2004) & ○ & 茨 & 城(2004) \\
\ & 熊 & 本(2005) & $\Delta$ & 茨 & 城(2005) \\
\hline
\end{tabular}
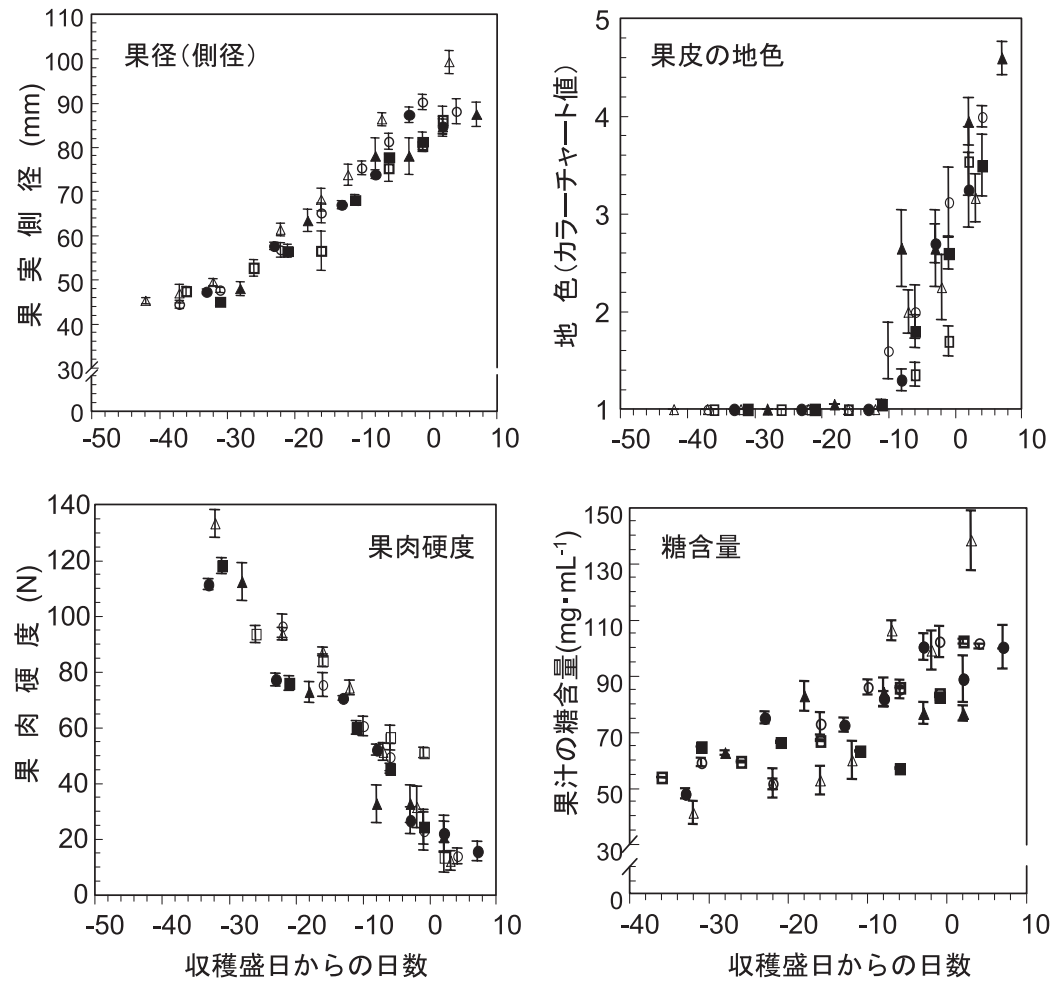

第 2 図 熊本と茨城に栽植されたモモ ‘あかつき’の成熟にともなら果実品質の変化（グラフ内のバーは標準誤差を示す $\mathrm{n}=5$ ） 


$$
\begin{aligned}
& \text { 一一熊 本(2003) 一- 茨 城(2003) } \\
& \text { - - 熊 本(2004) - - 茨 城(2004) } \\
& \triangle \text { - 熊 本(2005) } \triangle \text { 茨 城(2005) }
\end{aligned}
$$
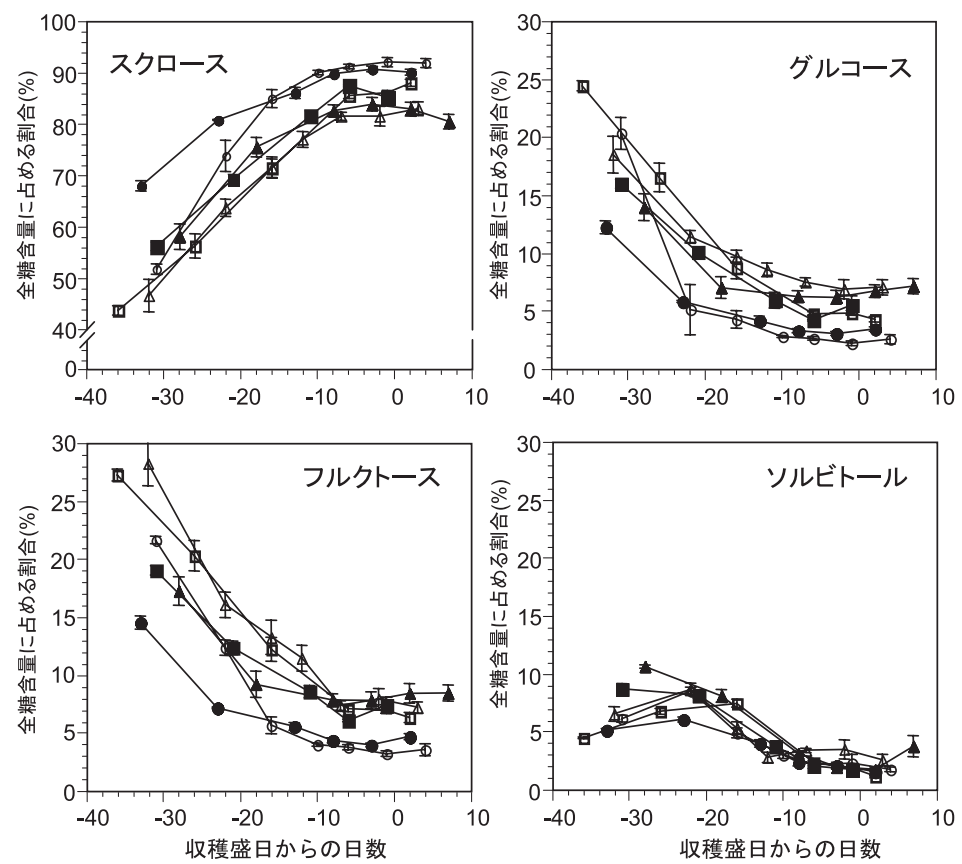

第 3 図 熊本と茨城に栽植されたモモ“あかつき’の成熟にともなら果汁の糖組成の変化（グラフ内のバーは標準誤差を示す $\mathrm{n}=5$ ）
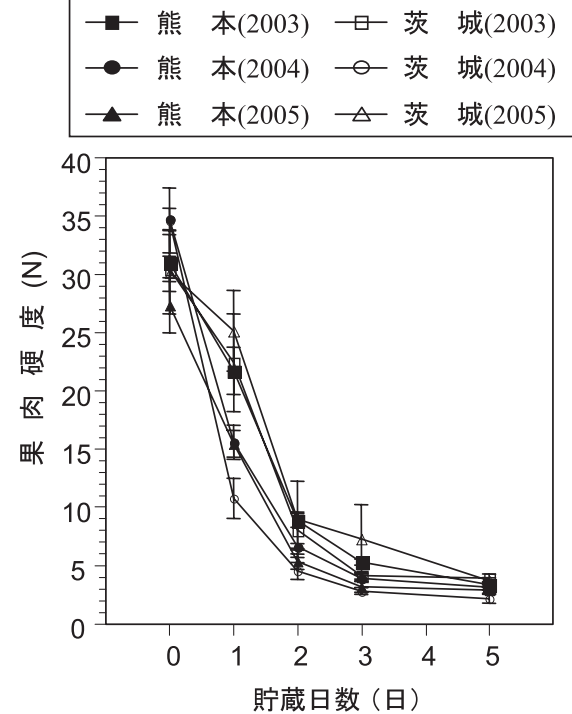

第 4 図 熊本と茨城に栽植されたモモ“あかつき’から果肉硬度 $30 \mathrm{~N}$ を目安に収穫した果実の貯蔵中に打政果肉硬度 の変化（グラフ内のバーは標準誤差を示す $\mathrm{n}=8 ）$

\section{4. 気温が果実の日持ち性に及ぼす影響}

果肉硬度約 $30 \mathrm{~N}$ を目安にして収穫した果実を $25^{\circ} \mathrm{C} て ゙$ 貯 蔵した場合の果肉硬度の変化を調査した。地域や年次に関 わらず，果実は貯蔵中急激に軟化し，貯蔵 2 日目で 5 $10 \mathrm{~N}$ になった（第 4 図）。年次と地域を要因として 2 元配 置分散分析を行った結果, 2004 年の果実では他の年に比べ
て貯蔵 1 日目の果肉硬度が低く日持ち性が劣る傾向にあっ たが，地域間には有意な差が認められなかった。

\section{考察}

調査した 3 か年のらち，2003 年は，両地域とも低温寡照 傾向にあった。特に，成熟期（収穫盛日前 4 週間）におい てその傾向が強く，日平均気温は他の 2 か年に比べ，熊本 では約 $2^{\circ} \mathrm{C}$, 茨城では $4 \sim 5^{\circ} \mathrm{C}$ 低かった. ただし，茨城の 幼果期の日平均気温は他の 2 か年より $0.5 \sim 1{ }^{\circ} \mathrm{C}$ 高かった. 一方, 2004 年は両地域ともに気温が高めに推移した. 特に, 茨城に打ける成熟期の気温が高く，熊本に比べてわずか $0.6^{\circ} \mathrm{C}$ 低いだけであった。 また，2005 年は，両地域で傾向 が異なり, 熊本は幼果期の気温が他の 2 か年よりも高かっ たが，それ以降は2004 年と同様であった。 これに対し，茨 城は他の 2 力年の中間的な気温変化を示した。このように 調査した 2 地域 3 か年に打温度条件は様々であった。 しかしながら，収穫盛日を基準にすると硬核指数の変化は 地域・年次に関係なく注一定であったことから，気温， 降水量等両地域に打いて調査期間中にみられた気象条件の 違いは，硬核開始以降の果実発育期間にはほとんど影響し ないと考えられた。一方，満開日から硬核開始日までの日 数は, 幼果期の気温が高い注ど短い傾向にあり，この期間 の果実発育は温度に影響される可能性が示された. モモ“白 鳳”に打いても, 幼果期の気温が高いほど細胞分裂停止時 期が前進し，硬核開始時期，硬核終了後の肥大開始時期お 
よび収穫時期が早まると報告されている（栗原ら，1965; 杉浦ら，2003)。また，このような傾向は，志村ら（2001）が 作成したモモ果実の発育速度（DVR）モデルともほぼ一致 した，果実発育期間は，いずれの年に抢いても熊本の方が 茨城よりも短いが，これは熊本の方が幼果期の気温が高い ために硬核が早く始まるためであると思われる。

成熟にともなら果実肥大, 果肉硬度の低下, 果皮の地色 の変化は，収穫盛日を基準にすると2地域 3 か年ともほぼ 同様の傾向が認められたことから，これらの変化は気温の 影響を皃とんど受けないものと考えられた。一方，成熟に ともなら総糖含量の変化は, 地域・年次間におけるばらつ きが大きかった. 特に, 2003 年および 2005 年の熊本では, 収穫直前に打ける増加が認められなかったが, これは降雨 量が多かったことによるものかも知れない.リンゴでは果 実発育期間中の温度によって果汁の糖組成が異なることが 報告されている（樫村ら，1992; 苫名・山田，1988a, 1988b; 山田ら，1988）が，モモに拈いては，果実発育期間の気温 と果汁の糖組成との間に一定の傾向は認められなかった。 な拉，2004 年においては両地域ともに成熟期間を通してス クロースの割合が高く，グルコースとフルクトースの占め る割合が低く推移したが，この理由は不明である.

果実の日持ち性は果実の熟度によって異なり,一般に熟度 が進む䚾ど劣る. 生産現場に打いて収穫期は食味や外観を総 合的に勘案して決定されるため, 収穫適期とされる果実熟度 は，産地や流通・販売条件等によって大きく異なる．このた め生産地の異なる果実の日持ち性を, 単純に比較することは できない，そこで，本試験においては，熊本と荻城に栽植さ れた ‘あかつき’ 樹から一定の果肉硬度で収穫した果実につ いて, 同一の貯蔵条件に打ける果肉硬度の変化を比較した。 その結果, 貯蔵中の果肉硬度变化と果実発育期間中の気温と の関係は認められず, 果実発育期間中の気温が日持ち性を大 きく左右することはないものと考えられた.

本試験の結果から，モモ果実の発育過程に拈いては幼果 期の気温が果実発育に影響し，この時期の気温上昇は果実 発育期間を短縮させ，その結果として収穫期を前進させる と考えられた。 このことから, 地球温暖化により, 果実発 育期間中の気温が上昇した場合, 満開後日数を目安に収穫 すると, 従来よりも熟度が進んだ状態で収穫する可能性が 高くなるものと思われる. 近年問題となっているモモの果肉 水浸状果（齋藤ら，2002; 高田ら，2005）や赤肉果（高田ら, 2006）は熟度の進んだ果実で発生が多いことから, 温暖化に よりその発生が助長されている可能性がある. また, 本試験 に颃いて，硬核時期を特定すれば収穫盛日をある程度予測 できる可能性が示されたことから，今後は収穫期を決定す る基準として硬核時期を利用できるかも知れない.

なお，本試験の結果は，特定の品種について得られたも のである. 温度に対する果実の反応は品種によって異なる （苫名・山田，1988a；山田ら，1988）ことも報告されてお り, 今後 ‘あかつき’ 以外の品種についても検討すること
が必要である.

\section{摘 要}

果実発育期間中の気温がモモ果実の発育に及ぼす影響を 解析するため, 気象条件の異なる熊本と茨城に栽植された モモ ‘あかつき’を用いて果実の発育や成熟に関わる様々 な形質の変化を 3 か年（2003～2005 年）にわたり調査し た。果実発育期間（満開日から収穫盛日までの期間）の平 均気温は, 熊本が荻城に比べて $1 \sim 2{ }^{\circ} \mathrm{C}$ 高かった. 一方, 成熟期（収穫盛日前 4 週間）の気温は，地域および年次間 差が大きく, 最も高かった 2004 年の熊本では $25.7^{\circ} \mathrm{C}$, 最

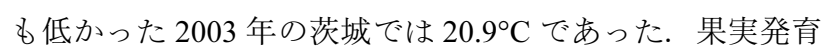
期間の日数は, 地域により大きく異なり熊本が茨城よりも $5 \sim 14$ 日短かった. 硬核開始日はいずれの年も熊本が茨城 よりも早かった。一方, 硬核開始から収穫盛日までの日数 は, 地域や年次に関係なくほぼ一定であった。したがって, 果実発育期間中の気温の上昇は満開日から硬核開始日まで の日数を短縮するが，硬核期以降の果実発育にはほとんど 影響を及ぼさないものと考えられた。 また，成熟にともな ら果実肥大，果肉硬度拈よび果皮の地色の変化についても 収穫盛日を基準にすると年次や地域に関係なくほぼ一定の 傾向を示し, 気温の影響はほとんど受けないと考えられた. 収穫後の日持ち性についても果肉硬度を揃えて収穫した場 合，果実発育期間の気温による影響は認められなかった。

謝 辞 本論文の作成に当たりご校閲いただいた（独） 農業・食品産業技術総合研究機構果樹研究所主任研究員杉 浦俊彦博士に謝意を表します。

\section{引用文献}

阿部 薰 - 井上重雄 - 志村浩雄他. 2001. 幼果期から新梢 伸長期の作業. モモの作業便利帳. p. 42. 農山漁村文 化協会. 東京.

Houghton, J. T., Y. Ding, D. J. Griggs, M. Noguer, P. J. van der Linden, X. Dai, K. Maskell and C. A. Johnson. 2001. Climate Change 2001: The Scientific Basis. p. 525-582. Cambridge Univ. Press, Cambridge.

樫村芳記・工藤和典・金子勝芳・吉岡博人. 1992. 成熟期 の気温がリンゴ ‘ふじ’ 果実の品質ならびに貯蔵性に 及ぼす影響. 園学雑. 61 (別 1) : 102-103.

栗原昭夫・志村 勲・金戸橘夫. 1965. モモ果実の成熟に 及ぼす温度の影響（第 1 報）果実の生育拈よび成熟日 数について. 園学要旨. 昭 40 秋 : 6 .

黒田浩之. 2004. アンケート調査からみたわが国の果樹農 業に対する気候温暖化の影響. p. 100-129. 平成 15 年 度果樹農業生産構造に関する調査報告書. 果樹農業に 対する気象変動の影響に関する調査.

Lombard, P. B., C. B. Cordy and E. Hansen. 1971. Relation of post-bloom temperatures to 'Bartlett' pear maturation. J. Amer. Soc. Hort. Sci. 96: 799-801. 
齋藤典義・古屋 栄・猪俣雅人. 2002. モモ果実に発生し た障害「夕つ症」の特徵. 園学雑. 71 (別 1) : 210 .

志村浩雄・渡邊栄子・増子俊明・阿部 薰・杉浦俊彦. 2001. モモ‘あかつき’の硬核期の特定と果実発育のモデル化. 園学雑. 70 (別 2) : 222 .

杉浦俊彦・本條 均. 1996. ニホンナシ果実成長の日射抒 よび気温からの予測モデルによる実証的研究. 園学雑. 65: 505-512.

杉浦俊彦・本條 均. 1997. ニホンナシの自発休眠覚醒と 温度との関係解明およびそのモデル化．農業気象． 53: $285-290$.

杉浦俊彦・本條 均・菅谷 博. 1995。 ニホンナシ果実生 育と気温の関係について。農業気象. 51:239-244.

杉浦俊彦・黒田浩之・吉岡博人・杉浦裕義・高辻豊二. 2004 . 温暖化がわが国の果樹生育に及ぼしている影響の現状 について. 園学雑. 73 (別 2) : 309 .

杉浦俊彦・高田教臣・黒田浩之・杉浦裕義. 2003. モモ“白
鳳’に打ける幼果期の温度が果実生育和よび細胞分裂 に及活寸影響. 園学雑. 72 (別 2) : 340 .

高田大輔・福田文夫・久保田尚浩. 2006. モモの赤肉果発 生に及活す着果位置，收穫日招よび袋掛けの影響。園 学研. 5: 33-37.

高田大輔・内倉康幸・今井理夫・福田文夫 - 笹部幸夫 藤井雄一郎・大塚雅子・久保田尚浩. 2005. モモ果実に 打郆る “水浸状果肉褐変症” の特徵. 園学研. 4: 429-433. 苫名 孝・山田 寿. 1988a. 栽培地を異にしたリンゴ果実 の品質と気温との関係. 園学雑. 56: 391-397.

苫名 孝・山田 寿. 1988b. 栽培地の異なるリンゴ果実に 打忷る成熟期の糖組成の変化. 園学雑. 57: 178-183.

山田 寿・浜本 清・杉浦 明・苫名 孝. 1988. リンゴ果 実の成熟に及活す果実温度の影響. 園学雑. 57: 173-177. 山崎利彦・鈴木勝征. 1980。果実の成熟度判定のための力 ラーチャートの作成とその利用に関する研究(第 1 報) カラーチャートの色特性. 果樹試報. A. 7: 19-44. 